\title{
Is Informal Sector Entrepreneurship Necessity- or Opportunity-driven? Some Lessons from Urban Brazil
}

\author{
Colin C. Williams ${ }^{1} \&$ Youssef Youssef ${ }^{2}$ \\ ${ }^{1}$ Management School, University of Sheffield, Sheffield, UK \\ ${ }^{2}$ Business School, Humber Institute of technology and Applied Learning, Toronto, Canada \\ Correspondence: Colin C. Williams, Management School, University of Sheffield, Sheffield, S1 4DP, UK. Tel: \\ 44-114-222-3476. E-mail: C.C.Williams@sheffield.ac.uk
}

Received: January 9, 2014

Accepted: January 23, 2014

Online Published: February 26, 2014

doi:10.5430/bmr.v3n1p41

URL: http://dx.doi.org/10.5430/bmr.v3n1p41

\begin{abstract}
The aim of this paper is to evaluate critically the widely-held assumption that entrepreneurs operating in the informal sector in developing nations are largely necessity-driven entrepreneurs, pushed into this entrepreneurial endeavour as a survival strategy in the absence of alternatives. Reporting an extensive 2003 survey conducted in Brazilian urban areas of informal sector entrepreneurs operating small businesses with less then five employees, the finding is that under half of the surveyed entrepreneurs are driven out of necessity into entrepreneurial endeavour in the informal economy. The outcome is a call to recognize the prevalence of opportunity-drivers amongst entrepreneurs operating in the informal economy and to reposition informal sector entrepreneurs more centre-stage in discussions of entrepreneurship and enterprise development.
\end{abstract}

Keywords: Informal economy, Underground economy, Entrepreneurship, Micro-enterprise, Small businesses, Enterprise development, Economic development, Brazil

\section{Introduction}

Over the past decade or so, a burgeoning literature has emerged which reveals that many entrepreneurs operate in the informal economy not only in the emerging economies of the global South (Bhatt, 2006; Bhowmik, 2007; Charmes, 1998; Cross, 2000; Cross and Morales, 2007; Das, 2003; Gurtoo and Williams, 2009; Unni and Rani, 2003) but also in the advanced economies of the global North (Llanes and Barbour, 2007; Schneider and Williams, 2013; Small Business Council, 2004; Venkatesh, 2006; Webb et al., 2009; Williams, 2006, 2009a,b,c, 2010). Until now, a widely-held belief has been that these entrepreneurs operating in the informal sector are marginalized populations engaged in such endeavour out of necessity as a survival practice and last resort in the absence of alternatives (Castells and Portes, 1989; Gallin, 2001; Lagos, 1995; Maldonado, 1995). This, however, has been an a priori assumption rather than an empirical finding. As Bhowmik (2007: 96) puts it, for such marginalized populations, informal sector entrepreneurship 'is the only means for survival'. The aim of this paper is to evaluate critically whether it is indeed the case that entrepreneurs operating in the informal sector in the global South are necessity-driven entrepreneurs. To evaluate this, empirical evidence will be reported from a survey of informal entrepreneurs operating small businesses with less than five employees in the main Brazilian urban areas. The result will be to advance understanding of the lived practices of entrepreneurship in the contemporary world, especially in relation to informal sector entrepreneurs in the global South.

To commence, therefore, this paper will briefly review how the literature on entrepreneurs' motives has become increasingly dominated by the classificatory schema that represents entrepreneurs as either necessity- or opportunity-driven, along with how the literature focusing on entrepreneurship in the informal economy has similarly, albeit often implicitly, depicted informal entrepreneurs as necessity-driven. Revealing that few empirical studies have so far evaluated the motives of informal sector entrepreneurs, to start to bridge this gap the second section will report an empirical study conducted in urban Brazil during 2003 that sought to understand the motivations of those entrepreneurs operating in the informal economy. The final section then draws some conclusions about the validity of depicting entrepreneurs operating in the informal sector as necessity-driven entrepreneurs.

Before commencing, however, it is necessary to define what is meant by informal entrepreneurship. Given that entrepreneurship has been a problematic and elusive concept for a long time and, as Anderson and Starnawska (2008: 
222) state, 'entrepreneurship means different things to different people', a working definition will be here employed appropriate to the task at hand. Hence, an entrepreneur is defined as somebody actively involved in starting a business or is the owner/manager of a business (Harding et al., 2006; Reynolds et al., 2003), whilst the informal economy is defined as those activities where monetary transactions are not declared to the state for tax, social security or labour law purposes but which are legal in all other respects (e.g., Evans et al., 2006; Williams, 2006; Williams and Windebank, 1998). The findings suggest that informal entrepreneurs can be classified as those owners/managers or are involved in the starting a new for profit business and not registered with the state authorities for tax, social security and labour law purposes, are legal in all other aspects.

\section{Informal Sector Entrepreneurship: necessity- or opportunity-driven?}

Over the past few decades, the entrepreneurship literature has used various analytical frameworks to explain the factors underpinning the decision to start-up a business (Baty, 1990; Bolton and Thompson, 2000; Brockhaus and Horowitz, 1986; Burns, 2001; Chell et al, 1991; Cooper, 1981; Kanter, 1983). Since the turn of the millennium, however, a particular classificatory scheme has become increasingly dominant in the entrepreneurship literature. Despite earlier warnings not to over-simplify the complex rationales of entrepreneurs (Rouse and Daellenbach, 1999), the classificatory schema which has come to the fore builds on the work of Bögenhold (1987) who differentiated between entrepreneurs motivated by economic needs and those driven by a desire for self-realisation. It has become increasingly common to distinguish between 'necessity' entrepreneurs pushed into entrepreneurship as a survival strategy in the absence of alternative means of livelihood, and 'opportunity' entrepreneurs pulled into this endeavour more out of choice (Aidis et al., 2006; Benz, 2009; Harding et al., 2005; Maritz, 2004; Minniti et al., 2006; Perunović, 2005; Reynolds et al., 2001, 2002; Smallbone and Welter, 2004). This structure/agency binary that views some entrepreneurs as 'necessity' entrepreneurs and others as 'opportunity' entrepreneurs has begun to move ever more centre-stage in studies of entrepreneurs' motives.

One prominent reason for its growing centrality is its usage in the Global Entrepreneurship Monitor (GEM), the predominant global survey of the degree and nature of entrepreneurship (Bosma and Harding, 2007; Bosma et al, 2008; Devins, 2009; Harding et al., 2006; Minniti et al., 2006; Reynolds et al., 2001, 2002). GEM aims to explore the link between entrepreneurship and economic development (Bosma and Harding, 2006; Bosma et al, 2008; Devins, 2009; Harding, 2008; Reynolds et al., 2001; 2002). To do this, it makes a distinction between 'necessity entrepreneurship', defined as people who view entrepreneurship as the best option available and not necessarily the preferred option, and 'opportunity entrepreneurship', defined as those who engage in entrepreneurship out of choice (Acs, 2006; Bosma et al, 2008; Hechaverria and Reynolds, 2009; Williams, 2007, 2008, 2009b; Williams et al., 2006, 2009, 2010; Williams and Lansky,2013). As Minniti et al (2006: 21) assert in relation to the GEM survey, 'In most countries ... nearly all individuals can be sorted into one of the two categories'. In other words, the assertion is that to be an entrepreneur out of choice means that one is not doing so out of necessity. Finding that the ratio of 'opportunity-to-necessity' entrepreneurs is greater in higher-income countries, and that nations dominated by opportunity entrepreneurs have a lower rate of early-stage business failure, the growing tendency has been to depict opportunity entrepreneurs as more desirable than necessity entrepreneurs (e.g., Minniti et al, 2006; Reynolds et al, 2001).

It is not only when studying legitimate entrepreneurs that this division between necessity and opportunity entrepreneurs has been prominent. It has also been increasingly applied to understanding the motives of entrepreneurs operating in the informal economy. Until now, that is, those entrepreneurs who operate wholly or partially in the informal economy have been widely assumed to be necessity-driven, pushed into this enterprise as a survival strategy in the absence of alternative options (e.g., Castells and Portes, 1989; Gallin, 2001; Lagos, 1995; Maldonado, 1995). As Travers (2002: 2) puts it, 'It is usually said that people do the work to earn extra money and left at that'. From street-sellers in the Dominican Republic (e.g. Itzigsohn, 2000) and Somalia (Little, 2003), through informal garment businesses in India (e.g., Das, 2003; Unni and Rani, 2003) and the Philippines (Doane et al, 2003), to home-based micro-enterprises in Mexico (e.g., Staudt, 1998) and Martinique (Browne, 2004), the consensus is that this is a sphere which people enter out of necessity as a survival strategy (e.g., Itzigsohn, 2000; Otero, 1994; Rakowski, 1994).

Over the past decade or so, however, the inverse has started to be argued. Commentators have begun to portray them as opportunity entrepreneurs (Cross, 2000; Gerxhani, 2004; Maloney, 2004; Snyder, 2004). As Gerxhani (2004: 274) asserts, such entrepreneurs

choose to participate in the informal economy because they find more autonomy, flexibility and freedom in this sector than in the formal one. In other words, participants have the freedom of operating their own 
business; they have flexibility in determining hours or days of operation; they can use and develop their creativity.

This is also the finding of Snyder (2004) in her study of informal entrepreneurs in New York City's East Village neighbourhood. She argues that although most literature assumes that external pressures (such as discrimination, economic restructuring and unemployment) force people into the informal economy, most of the 50 informal sector entrepreneurs she studied were doing so voluntarily. Most were opportunity entrepreneurs engaged in this realm to set their careers on a new path and transform their work identity or reveal their true selves. Even those who began as necessity-driven entrepreneurs, joining due to constrained opportunities in the formal economy, tended to develop a long-term commitment to their informal sector enterprises. For her, therefore, informal entrepreneurs are opportunity driven.

This is also the finding of Cross (2000) who finds that although street vendors have been conventionally represented as necessity-driven entrepreneurs, most he studied did so out of choice. These entrepreneurs voluntarily operate in the informal economy to avoid the costs, time and effort of formal registration (Cross and Morales, 2007; De Soto, 2001) and because it offers potential benefits not found in formal economy, including flexible hours, job training, and entry to the labor force, opportunity for economic independence, better wages and avoidance of taxes and inefficient government regulation (Maloney, 2004).

Many of these studies depict informal entrepreneurs as either universally necessity or opportunity driven. One of the first to transcend such either/or thinking was a survey by Lozano (1989) of 50 dealers at flea markets in Northern California. She differentiates between voluntary and involuntary entrants to this market. One-fifth were voluntary entrants who explained their participation in terms of intense dissatisfaction with the routine and authority of the formal workplace and had opted for informal entrepreneurship for reasons of personal autonomy and flexibility and to 'be my own boss'. The remaining four-fifths were involuntary entrants who had either lost their formal job, had insufficient income from employment, pensions or welfare payments to cover normal living expenses and levels of indebtedness; or were unable to find a formal job.

This then led to a series of studies, mostly in the global North and based on small-scale studies, which explored the ratios of necessity-to-opportunity informal entrepreneurship. These studies conducted in England (Williams, 2006, 2007, 2008a, 2009a, 2010; Williams and Nadin, 2013a,b; Williams et al., 2013a), Ukraine (Round and Williams, 2008; Williams et al., 2006, 2009, 2010, 2013b) and Russia (Round et al., 2008; Williams and Round, 2009b; Williams, 2009b) reveal the socio-spatial contingency of informal entrepreneurs' motives in terms of the ratio of necessity-to-opportunity entrepreneurship with greater proportions of necessity-driven informal entrepreneurship in deprived populations and opportunity entrepreneurship in more affluent populations.

In the global South, meanwhile, the studies so far conducted, mostly in Latin America (see Perry et al., 2009) but also India (Williams and Gurtoo, 2013) again reveal the prevalence of opportunity-drivers in informal sector entrepreneurs' rationales, and call for what they call 'exit' (opportunity-driven entrepreneurship) to be added to exclusion (necessity-driven entrepreneurship) when explaining entrepreneurship in the informal sector.

As Perry and Maloney (2009: 2) point out, these two lenses, focusing, respectively, on informality driven by exclusion from state benefits and on voluntary exit decisions resulting from private cost-benefit calculations, are complementary rather than competing analytical frameworks". Here, therefore, we further contribute to this emergent analytical understanding that informal entrepreneurs may be other than necessity-driven by reporting some evidence from urban Brazil of entrepreneurs in the informal sector operating small businesses with less than five employees.

\section{Method}

\subsection{Sampling Procedure}

In order to evaluate critically whether entrepreneurship in the informal economy is always necessity-driven, we here report a survey of the urban informal sector (Pesquisa Economia Informal Urbana, ECINF) conducted in Brazil during 2003 by the Brazilian Institute for Geography and Statistics (IBGE, Instituto Brasileiro de Geografia e Estadística), which is the national census bureau. This household survey generates representative data of urban self-employed and micro-firm owners with at most five paid employees, excluding domestic workers, in urban Brazil. In this survey, a total of 54,595 households were interviewed. From the 40,235 individuals identified as either self-employed or owners of small businesses with at most five paid employees, just 8 per cent reported paying taxes and/or making social security contributions.The vast majority, therefore, were informal entrepreneurs.

The stratified sampling design, in two stages, was designed to provide a representative sample of these entrepreneurs 
both geographically and in terms of the sectors in which they work. The first stage, therefore, involved deciding about the number of households to be surveyed in main geographical areas that of urban Brazil. In this regard, and in order to achieve a representative sample, data from IBGE's 2000 census was used to order to identify these entrepreneurs in the 26 Brazilian states, including the federal district, and also each of the 10 Metropolitan Areas (Belém, Fortaleza, Recife, Salvador, Belo Horizonte, Vitória, Rio de Janeiro, São Paulo, Curitiba and Porto Alegre) and the municipality of Goiânia. Having determined the number of informal entrepreneurs to be interviewed in each of the selected areas, the second stage was generated a representative sample of these entrepreneurs by the sectors in which they work and their spatial location.

\subsection{Measures and Research Design}

In terms of the nature of the questionnaire, to collect data for ECINF, two surveys were applied. First, the ECINF household questionnaire aimed to gather socio-demographic data on each of the household members who were ten years old or older, and their employment status. This also aimed to investigate whether they were self-employed or employers that have employed up to five employees. In the case of a household member identified as being self-employed or employer with up to five employees, the second survey was deployed, which is the ECINF individual questionnaire and aims to understand the characteristics of their entrepreneurial activity.

The first section of this second questionnaire collected data about the nature of their economic activity, using the Brazilian National Classification of Economic Activities to classify these activities. The Brazilian National Classification of Economic Activities is an adaptation of the United Nations third revision of the International Standard Industrial Classification (ISIC) of economic activities. In the second section, data were collected on income, expenses, equipment and geographic location of the production along with the number of employees. The third section aimed to evaluate the organisation, examining variables such as the formalisation and visibility of these economic units, which includes the type of accounting methods, the employees' status, and whether the enterprise was registered with the authorities, has a license to trade and if they are making tax and social contribution payments. In the fourth section, the investigation was focused on the main problems that are confronting the business, analysing their plans for the future with regard to expansion, retraction, maintenance or even considering closing the business, including the challenges faced to regularise the business. The fifth section investigated the main reason for starting up the business using a list of reasons that covered the range of necessity- and opportunity-driven explanations for participating in entrepreneurship. The sixth section investigated the characteristics of the entrepreneurs, such whether they have second jobs, their education level and prior job history. The seventh and final section then collected data on the surveyed entrepreneur's access to a variety of services, such as credit, and the payments methods they used to acquire goods and/or raw materials, as well as the locations of their customers.

In the next section, therefore, we focus upon the responses regarding their motives for engaging in informal entrepreneurship in terms of whether they were necessity-driven or opportunity-driven to do so, and provide some descriptive statistics on who is necessity-driven and opportunity-driven. The intention, in doing so, is to provide one of the first insights into the degree to which informal sector in emerging economies are in fact necessity-driven, as is widely purported to be the case.

\section{Results}

The finding of this survey is that 86.7 per cent of the informal entrepreneurs in urban Brazil were sole traders without any employees and 13.3 per cent were operating businesses with five employees or less. Table 1 reveals that two-thirds of these informal entrepreneurs are men ( 66 per cent), rising to three-quarters ( 73 per cent) amongst those who have employees. In terms of earnings, the survey reveals that men earn on average 67 per cent more than women from their informal entrepreneurship. This displays how informal entrepreneurship reinforces the gender disparities in the wider labour market. Most informal entrepreneurs, furthermore, are in the prime working age population aged 25-59 years old ( 83 per cent of all informal entrepreneurs), with nearly one-third (31 per cent) having completed at least their education to high school level, with 8 per cent having a university degree. Just 9 per cent have no education or less than one year of education. Of those informal entrepreneurs with employees, moreover, around one in five (18 per cent) have a university degree, thus calling into question the depiction of informal entrepreneurs as largely composed of the illiterate and uneducated. 
Table 1. Socio-demographic characteristics of informal entrepreneurs in urban Brazil, 2003

\begin{tabular}{|c|c|c|c|}
\hline$\%$ & All & Sole traders & $\begin{array}{r}\text { Entrepreneurs with } \\
\text { employees }\end{array}$ \\
\hline \multicolumn{4}{|l|}{ Gender: } \\
\hline Man & 66.3 & 65.3 & 72.6 \\
\hline Woman & 33.7 & 34.7 & 27.4 \\
\hline$\chi^{2}$ & & $\chi^{2}=9.6, p<0.005$ & $\chi^{2}=12.1, p<0.005$ \\
\hline \multicolumn{4}{|l|}{ Average income (R\$): } \\
\hline All & 753 & 623 & 1606 \\
\hline Man & 869 & 727 & 1701 \\
\hline Woman & 520 & 424 & 1341 \\
\hline$\chi^{2}$ & & $\chi^{2}=9.2, p<0.005$ & $\chi^{2}=20.1, p<0.005$ \\
\hline \multicolumn{4}{|l|}{ Age Group: } \\
\hline $10-17$ years old & 0.9 & 1.0 & - \\
\hline 18 - 24 years old & 7.1 & 7.6 & 3.8 \\
\hline 25 - 39 years old & 37.3 & 36.7 & 41.3 \\
\hline 40 - 59 years old & 45.6 & 45.3 & 48.0 \\
\hline $60+$ years old & 9.1 & 9.4 & 6.8 \\
\hline No response & 0.1 & - & - \\
\hline$\chi^{2}$ & & $\chi^{2}=16.9, p<0.005$ & $\chi^{2}=20.2, p<0.005$ \\
\hline \multicolumn{4}{|l|}{ Educational level: } \\
\hline No education or $<1$ year in school & 9.1 & 9.9 & 3.6 \\
\hline Basic education not completed & 37.1 & 39.0 & 24.1 \\
\hline Basic education completed & 13.9 & 14.1 & 12.6 \\
\hline High School incomplete & 8.8 & 8.9 & 8.0 \\
\hline High School completed & 20.0 & 18.8 & 28.0 \\
\hline University degree not completed & 3.1 & 2.7 & 5.3 \\
\hline University degree & 7.9 & 6.3 & 18.3 \\
\hline No response & 0.2 & 0.2 & 0.1 \\
\hline$\chi^{2}$ & & $\chi^{2}=29.1, p<0.005$ & $\chi^{2}=36.5, p<0.005$ \\
\hline
\end{tabular}

Note: In all cases, $\mathrm{H}_{\mathrm{o}}$ is rejected within a 99.5 per cent confidence interval that there are no variations in the gender/income of men and women/age/education/age started working of sole traders and entrepreneurs with employees.

Source: IBGE, Diretoria de Pesquisas, Coordenação de Trabalho e Rendimento, Economia Informal Urbana 2003.

Turning to the characteristics of their entrepreneurial endeavour, Table 2 displays that over half ( 52 per cent) of informal entrepreneurs work for 40 hours or more each week, rising to 70 per cent amongst those informal entrepreneurs with employees. The vast majority work for 21 days and over each month. On the whole, therefore, informal entrepreneurship in Brazil is not part-time endeavour used to top-up other earnings, as has been found in advanced western economies (Williams, 2004, 2006). Indeed, just 19 per cent worked less than 20 hours per week and 15 per cent less than 15 days per month. Instead, there appears to be segmented labour market of informal entrepreneurs with at one end, those engaged in informal entrepreneurship as a main means of livelihood and full-time occupation and at the other end, those engaged in such informal entrepreneurial endeavour on a more part-time basis as a means of topping up household earnings. Examining the activities in which they engage, the most common sectors are commerce and repairs (33 per cent), construction (17 per cent), primary and manufacturing industry (16 per cent), social and personal services ( 8 per cent), transport storage and distribution ( 8 per cent) and hospitality and food services ( 7 per cent). Many of these businesses are long-established with 31 per cent being established for over 10 years and a further 26 per cent for 5-10 years. 
Table 2. Characteristics of business activity of informal entrepreneurs in urban Brazil, 2003

\begin{tabular}{|c|c|c|c|}
\hline$\%$ of respondents & All & Sole traders & $\begin{array}{r}\text { Entrepreneurs with } \\
\text { employees }\end{array}$ \\
\hline \multicolumn{4}{|l|}{ Hours worked each week: } \\
\hline$<20$ hours & 19.2 & 21.1 & 6.3 \\
\hline $20-40$ hours & 28.9 & 29.7 & 23.3 \\
\hline $40-60$ hours & 37.1 & 35.2 & 49.6 \\
\hline$>60$ hours & 14.5 & 13.6 & 20.5 \\
\hline No response & 0.3 & 0.3 & 0.3 \\
\hline$\chi^{2}$ & & $\chi^{2}=18.1, p<0.005$ & $\chi^{2}=31.2, p<0.005$ \\
\hline \multicolumn{4}{|l|}{ Days worked each month: } \\
\hline$<15$ days & 15.2 & 16.5 & 6.7 \\
\hline $15-20$ days & 23.3 & 23.5 & 20.3 \\
\hline $21-30$ days & 61.3 & 59.5 & 79.0 \\
\hline No response & 0.1 & 0.2 & 0.0 \\
\hline 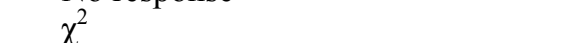 & & $\chi^{2}=16.1, p<0.005$ & $\chi^{2}=26.2, p<0.005$ \\
\hline \multicolumn{4}{|l|}{ Sector: } \\
\hline Primary and manufacturing industry & 16.0 & 16.1 & 15.5 \\
\hline Construction & 16.8 & 17.4 & 12.4 \\
\hline Commerce and repairs & 33.2 & 32.8 & 36.2 \\
\hline Hospitality and food services & 7.0 & 6.7 & 9.0 \\
\hline Transport, storage and distribution & 7.8 & 8.3 & 4.1 \\
\hline Estate, renting and business services & 6.7 & 6.3 & 9.3 \\
\hline Education, health and social services & 3.4 & 2.8 & 7.7 \\
\hline Other social \& personal services & 8.0 & 8.4 & 5.2 \\
\hline Other activities & 0.3 & 0.3 & 0.4 \\
\hline No response & 0.8 & 0.9 & 0.1 \\
\hline 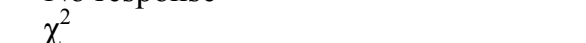 & & $\chi^{2}=26.3, p<0.005$ & $\chi^{2}=28.5, p<0.005$ \\
\hline \multicolumn{4}{|l|}{ Length of time business established: } \\
\hline$<1$ year & 12.3 & 12.9 & 8.4 \\
\hline $1-3$ years & 19.8 & 20.1 & 16.9 \\
\hline $3-5$ years & 11.7 & 11.5 & 12.8 \\
\hline $5-10$ years & 25.6 & 25.4 & 26.8 \\
\hline$>10$ years & 30.6 & 29.9 & 35.0 \\
\hline$\chi^{2}$ & & $\chi^{2}=27.2, p<0.005$ & $\chi^{2}=29.4, p<0.005$ \\
\hline \multicolumn{4}{|l|}{ Location of Business: } \\
\hline Wholly home-based business & 27.3 & 28.6 & 17.3 \\
\hline Wholly outside home & 65.1 & 63.2 & 79.1 \\
\hline - store/workshop & 20.3 & 15.5 & 56.0 \\
\hline - customer's home & 27.5 & 29.2 & 15.1 \\
\hline - co-owner's home & 0.1 & 0.1 & 0.1 \\
\hline - vehicle & 6.4 & 6.9 & 3.4 \\
\hline - public place & 8.8 & 9.5 & 3.4 \\
\hline - other & 1.7 & 1.8 & 1.0 \\
\hline - no disclosed & 0.2 & 0.2 & 0.1 \\
\hline Both home-based and external & 7.6 & 8.2 & 3.6 \\
\hline$\chi^{2}$ & & $\chi^{2}=20.2, p<0.005$ & $\chi^{2}=29.1, \mathrm{p}<0.005$ \\
\hline \multicolumn{4}{|l|}{ Customer base: } \\
\hline Varied customer base & 83.6 & 83.6 & 83.9 \\
\hline Fixed customer base & 16.4 & 16.4 & 16.0 \\
\hline - only one customer & 4.1 & 4.1 & 3.1 \\
\hline - several customers & 9.5 & 9.5 & 8.7 \\
\hline - big businesses & 0.7 & 0.7 & 1.8 \\
\hline - small businesses & 1.9 & 1.9 & 2.0 \\
\hline - government \& other agencies & 0.1 & 0.1 & 0.3 \\
\hline$\chi^{2}$ & & $\chi^{2}=20.1, p<0.005$ & $\chi^{2}=22.2, p<0.005$ \\
\hline
\end{tabular}

Note: In all cases, $\mathrm{H}_{\mathrm{o}}$ is rejected within a 99.5 per cent confidence interval that there are no variations in the hours worked each week/days worked per month/sectors of activity of sole traders and employers with employees. 
Over one quarter (27.3 per cent) of these informal entrepreneurs, moreover, operate home-based enterprises, clearly signalling that if the full range of informal entrepreneurship is to be captured in surveys, then a household rather than business premise survey is required (Mason et al., 2009). This is further reinforced when it is recognised an additional quarter of informal entrepreneurs (27.5 per cent) work from the customer's home, meaning that over a half of informal entrepreneurs will be missed if a business premise survey is conducted. Indeed, only one-fifth (20.3 per cent) of the informal entrepreneurs operate from a workshop or store, displaying the limited range of informal entrepreneurship captured by a business premise survey.

Informal entrepreneurship is sometimes depicted to be a result of the sub-contracting of production into the informal sector where people who might have been former employees engage in 'false self-employment' for one supplier only (Castells and Portes, 1989; Gallin, 2001; Portes, 1994; Portes and Haller, 2004; Portes and Roberts, 2005; Sassen, 1997). The finding of this survey, however, is that just 4.1 per cent of these micro-enterprises work for one customer only, just 0.7 per cent for big businesses and 1.9 per cent for small businesses. It therefore appears that entrepreneurial endeavour in the informal economy in Brazil is not a result of sub-contracting production functions down the supply chain to the informal sector. Nevertheless, it might still be the case, as other commentaries based on the depiction of these informal entrepreneur as necessity-based entrepreneurs argue, that this realm represents an absorber of surplus labour and provider of income earning opportunities for those excluded from the formal labour market (Bhatt, 2006; Nelson and Bruijn, 2005; Tokman, 2001).

What were their reasons, therefore, for starting their informal business venture? As the literature review revealed, the widespread assumption has been that many are pushed into this endeavour out of necessity as a survival strategy in the absence of alternative means of livelihood. In recent years, however, it has been recognised that at least some informal sector entrepreneurs are opportunity-driven and doing so more out of choice rather than necessity. The first clue that informal entrepreneurs are not always pushed out of necessity into this endeavour is that of the 27 per cent who were in formal employment before establishing their micro-enterprise, only 31 per cent cited redundancy as their reason for leaving their formal employment. The remaining 69 per cent leaving formal employment did so for other more voluntary reasons such as to achieve personal goals (e.g., desire for autonomy and flexibility).

To evaluate the extent to which informal sector entrepreneurs are necessity-driven, therefore, participants were asked which of ten reasons constituted the main motivation for starting their micro-business. Table 3 groups these reasons according to whether they are necessity-or opportunity-driven explanations for informal entrepreneurship.

Table 3. Motives for starting informal sector micro-enterprise in urban Brazil, 2003

\begin{tabular}{lrrr}
\hline$\%$ of respondents & All & $\begin{array}{r}\text { Sole traders } \\
\text { Entrepreneurs with } \\
\text { employees }\end{array}$ \\
\hline Necessity-driven explanations: & 48.7 & 52.2 & 23.7 \\
$\quad$ Did not find a formal job & 31.1 & 33.2 & 16.0 \\
$\quad$ To supplement my net income & 17.6 & 19.0 & 7.7 \\
Opportunity-driven explanations: & 45.3 & 41.9 & 69.4 \\
$\quad$ Independence & 16.5 & 15.4 & 24.3 \\
$\quad$ Experience in the area & 8.4 & 7.6 & 13.9 \\
$\quad$ Family tradition & 8.1 & 7.6 & 11.8 \\
$\quad$ Promising Business & 7.4 & 6.8 & 11.3 \\
$\quad$ It was a secondary job & 2.1 & 2.0 & 3.0 \\
$\quad$ Work time flexibility & 1.9 & 2.0 & 0.9 \\
$\quad$ Opportunity presented by a partner & 1.0 & 0.6 & 4.2 \\
Other reasons & 5.8 & 5.7 & 6.6 \\
No response & 0.2 & 0.2 & 0.3 \\
$\chi^{2}$ & & $\chi^{2}=28.3, \mathrm{p}<0.005$ & $\chi^{2}=43.1, \mathrm{p}<0.005$ \\
\hline
\end{tabular}

Note: $\chi^{2}>25.19$ in all cases, leading us to reject $\mathrm{H}_{\mathrm{o}}$ within a 99.5 per cent confidence interval that there are no variations in the reasons for participating in informal entrepreneurship between sole traders and entrepreneurs with employees. Source: IBGE, Diretoria de Pesquisas, Coordenação de Trabalho e Rendimento, Economia Informal Urbana 2003 
The finding is that less than half (48.7 percent) of informal entrepreneurs report necessity-drivers such as their exclusion from the formal economy or the need to earn additional income. For many informal entrepreneurs, therefore, participation in this endeavour is a matter of choice, rather than due to a lack of choice. Some 16.5 per cent state that their main reason was to seek independence, 8.4 per cent that it was due to their experience or skills in the business, 8.1 per cent that they were following a family tradition, 7.4 per cent because it represented a promising business opportunity, 2.1 per cent that it was a secondary job, 1.9 per cent due to the flexibility in their working time that it afforded and 1 per cent because of the opportunity presented by their partner.

When comparing the sole traders' motives with those who have five employees or fewer, however, some marked differences stand out. Whilst some one half of informal sector traders are primarily necessity-driven, this is the case for less than a quarter (23.7 per cent) of informal entrepreneurs with five employees or fewer. For the latter micro-enterprises, the drivers are far more opportunity-oriented, such as the desire for independence.

In sum, informal sector entrepreneurs urban Brazil are not purely pushed into this realm out of necessity due to their exclusion from the formal labour market and in the absence of any alternative means of livelihood. Instead, around a half of informal sector entrepreneurs in urban Brazil do so more as a matter of choice, rather than due to a lack of choice. This is especially the case amongst owners of micro-enterprises operating in the informal sector with five or less employees.

\section{Discussion and Conclusions}

This paper has evaluated critically the assumption that entrepreneurs operating micro-enterprises in the informal sector in developing nations do so out of necessity due to their exclusion from the formal labour market and/or the absence of alternative means of livelihood. In this sense, empirical evidence taken from a 2003 survey of informal entrepreneurs in the main Brazilian urban areas was reported.

The finding is that less than half of these informal entrepreneurs operating small business with a maximum of five employees are driven out of necessity into this realm due to their exclusion from the formal economy or due to their need to earn additional income. Instead, for many informal sector entrepreneurs, participation in this endeavour is a matter of choice, rather than due to a lack of choice, such as because they were seeking independence (16.5 per cent), had experience or skills in the business ( 8.4 per cent), were following a family tradition (8.1 per cent), had identified a promising business opportunity ( 7.4 per cent), that it was a secondary job ( 2.1 per cent), sought flexibility in their working time (1.9 per cent) and had taken up an opportunity presented by their business partner ( 1 per cent). Necessity drivers are even less prevalent amongst informal sectors entrepreneurs operating micro-enterprises with five or less employees, with only a quarter citing necessity drivers.

The outcome is that informal sector entrepreneurship needs to be not only re-read as often opportunity driven but their role in economic development needs to be rethought. To facilitate this re-reading of informal sector entrepreneurship as often opportunity-driven, further research is now required in a wider variety of contexts to evaluate whether this remains valid in different populations. Further research should thus be conducted in other developing countries to evaluate whether this is indeed the case. If this is the case, then there will be a need to re-think the role of informal sector entrepreneurs in economic development. Until now, the stance has been that these so-called necessity entrepreneurs contribute little to economic and enterprise development and if any, represent a hindrance to economic development. This paper, however, has revealed that many informal sector entrepreneurs are opportunity driven and are seeking to develop their business ventures. To pursue the eradication of informal sector entrepreneurship, therefore, will repress precisely the entrepreneurship and enterprise culture that many governments are seeking to nurture. Instead, what is perhaps required is a more concerted effort to facilitate the formalisation of such informal sector entrepreneurship and to reposition the regularisation of these informal sector micro-enterprises more centre-stage in discussions of entrepreneurship and enterprise development. This will require an evaluation of the range of policy measures available for facilitating the regularization of these informal sector micro-enterprises along with which are effective in different contexts (see Williams and Nadin, 2012a,b, 2013b). Hopefully, therefore, this paper will encourage further research to contest the depiction of informal sector entrepreneurs as necessity-driven in other populations as well as greater policy discussion about how to harness this large realm of entrepreneurship on a global level. If this paper stimulates such research and debate, then it will have achieved its objectives. 


\section{References}

Acs, Z. J. (2006). How is entrepreneurship good for economic growth?' Innovations, 1, 97-107. http://dx.doi.org/10.1162/itgg.2006.1.1.97

Aidis, R., Welter, F., Smallbone, D. \& Isakova, N. (2007). Female entrepreneurship in transition economies: the case of Lithuania and Ukraine. Feminist Economics, 13, 157-183. http://dx.doi.org/10.1080/13545700601184831

Anderson, A. R. \& Starnawska, M. (2008). Research practices in entrepreneurship: problems of definition, description and meaning. International Journal of Entrepreneurship and Innovation, 9, 221-230. http://dx.doi.org/10.5367/000000008786208731

Baty, G. (1990). Entrepreneurship in the Nineties. London: Prentice Hall.

Benz, M. (2009). Entrepreneurship as a non-profit seeking activity. International Entrepreneurship and Management Journal, 5, 23-44. http://dx.doi.org/10.1007/s11365-006-0031-y

Bhatt, E. (2006). We are poor but so many: the story of self-employed women in India. Oxford: Oxford University Press.

Bhowmik, S. K. (2007). Street vending in urban India: the struggle for recognition. In J. Cross and A. Morales (Eds.), Street entrepreneurs: people, place and politics in local and global perspective (pp. 89-123). London: Routledge. http://dx.doi.org/10.4324/9780203086742.ch6

Bögenhold, D. (1987). De Gründerboom: realität unde mythos de neuen Selbständigkeit. Frankfurt: Campus.

Bolton, B. \& Thompson, J. (2000). Entrepreneurs: talent, temperament, technique. Oxford: Butterworth- Heinemann.

Bosma, N. \& Harding, R. (2007). Global Entrepreneurship Monitor: GEM 2006 results. London: London Business School.

Bosma, N., Jones, K., Autio, K. \& Levie, J. (2008). Global Entrepreneurship Monitor: 2007 Executive Report. London: Global Entrepreneurship Monitor Consortium.

Brockhaus, R. H. \& Horowitz, P. S. (1986). The psychology of the entrepreneur. Entrepreneurship Theory and Practice, 23, 29-45.

Browne, K. E. (2004). Creole Economics: Caribbean cunning under the French flag. Austin: University of Texas.

Burns, P. (2001). Entrepreneurship and Small Business. Basingstoke: Palgrave.

Castells, M. \& Portes, A. (1989). World underneath: the origins, dynamics and effects of the informal economy. In A. Portes, M. Castells and L. A. Benton (Eds.), The Informal Economy: studies in advanced and less developing countries (pp.19-42). Baltimore: John Hopkins University Press.

Charmes, J. (2009) Concepts, measurement and trends. In J. P. Jütting and J. R. Laiglesia (Eds.), Is Informal Normal? Towards more and better jobs in developing countries (pp. 19-35). Paris: OECD.

Chell, E., Haworth, J. \& Brearly, S. (1991). The Entrepreneurial Personality: concepts, cases and categories. London: Routledge.

Cooper, A. C. (1981). Strategic management: new ventures and small businesses. Long Range Planning, 14, 39-45. http://dx.doi.org/10.1016/0024-6301(81)90006-6

Cox, P. (2009) Foreword. In G. E. Perry, W. F. Maloney, O. S. Arias, P. Fajnzylber, A. D. Mason and J. Saavedra-Chanduvi (Eds.), Informality: exit and exclusion (pp. 1-20). Washington DC: World Bank.

Cross, J. \& Morales, A., (2007). Introduction: locating street markets in the modern/postmodern world. In J. Cross and A. Morales (Eds.), Street entrepreneurs: people, place and politics in local and global perspective (pp. 1-13). London: Routledge.

Cross, J. C. (2000). Street vendors, modernity and postmodernity: conflict and compromise in the global economy. International Journal of Sociology and Social Policy, 20, 29-51. http://dx.doi.org/10.1108/01443330010789061

Das, K. (2003). Income and employment in informal manufacturing: a case study. In R. Jhabvala, R. M. Sudarshan and J. Unni (Eds.), Informal Economy Centrestage: new structures of employment (pp. 62-103). London: Sage.

De Soto, H. (1989). The Other Path: the economic answer to terrorism. London: Harper and Row.

De Soto, H. (2001). The Mystery of Capital: why capitalism triumphs in the West and fails everywhere else. London: Black Swan. 
Devins, D. (2009). Enterprise in deprived areas: what role for start-ups? International Journal of Entrepreneurship and Small Business, 8, 486-498. http://dx.doi.org/10.1504/IJESB.2009.025694

Doane, D., Srikajon, D. \& Ofrenco, R. (2003). Social protection for informal workers in the garment industry. In F. Lund and J. Nicholson (Eds.), Chains of Production, Ladders of Protection: social protection for workers in the informal economy (pp. 89-123). Durban: School of Development Studies, University of Natal.

Evans, M., Syrett, S. \& Williams, C.C. (2006). Informal Economic Activities and Deprived Neighbourhoods. London: Department of Communities and Local Government.

Gallin, D. (2001). Propositions on trade unions and informal employment in time of globalization. Antipode, 19, 531-49. http://dx.doi.org/10.1111/1467-8330.00197

Gerxhani, K. (2004). The informal sector in developed and less developed countries: a literature survey. Public Choice, 120, 267-300. http://dx.doi.org/10.1023/B:PUCH.0000044287.88147.5e

Gurtoo, A. \& Williams, C. C. (2009). Entrepreneurship and the informal sector: some lessons from India. International Journal of Entrepreneurship and Innovation, 10, 55-62. http://dx.doi.org/10.5367/000000009787414280

Gurtoo, A. \& Williams, C. C. (2011). Women entrepreneurs in the Indian informal sector: marginalisation dynamics or institutional rational choice? International Journal of Gender and Entrepreneurship, 3, 6-22. http://dx.doi.org/10.1108/17566261111114953

Harding, R. (2003). Global Entrepreneurship Monitor Business start-up activity. London: London Business School.

Harding, R. (2006). Global Entrepreneurship Monitor: United Kingdom 2006. London: Global Entrepreneurship Monitor Consortium.

Harding, R., Brooksbank, D., Hart, M., Jones-Evans, D., Levie, J., O’Reilly, J. \& Walker, J. (2006). Global Entrepreneurship Monitor United Kingdom 2005. London: London Business School.

Hechavarria, D. M. \& Reynolds, P. D. (2009). Cultural norms and business start-ups: the impact of national values on opportunity and necessity entrepreneurs. International Entrepreneurship and Management Journal, 5, 417-437. http://dx.doi.org/10.1007/s11365-009-0115-6

Itzigsohn, J. (2000). Developing Poverty: the state, labor market deregulation and the informal economy in Costa Rica and the Dominican Republic. Pennsylvania: Pennsylvania State University Press.

Jütting, J. P. \& Laiglesia, J. R. (2009). Employment, poverty reduction and development: what's new? In J. P. Jütting and J. R. Laiglesia (Eds.), Is Informal Normal? Towards more and better jobs in developing countries (pp. 142-65). Paris: OECD.

Kanter, R. M. (1983). The Change Masters. New York: Simon and Schuster.

Lagos, R. A. (1995). Formalising the informal sector: barriers and costs. Development and Change, 26, 110-31. http://dx.doi.org/10.1111/j.1467-7660.1995.tb00545.x

Little, P. D. (2003). Somalia: economy without state. Bloomington: Indiana University Press.

Llanes, M. \& Barbour, A. (2007). Self-employed and micro-entrepreneurs: informal trading and the journey towards formalization. London: Community Links.

Lozano, B. (1989). The Invisible Workforce: transforming American business with outside and home-based workers. New York: The Free Press.

Maldonado, C. (1995). The informal sector: legalization or laissez-faire?', International Labour Review 134, 705-728.

Maloney, W. F. (2004). Informality revisited. World Development, 32, 1159-1178. http://dx.doi.org/10.1016/j.worlddev.2004.01.008

Maritz, A. (2004). New Zealand necessity entrepreneurs. International Journal of Entrepreneurship and Small Business, 1, 255-264. http://dx.doi.org/10.1504/IJESB.2004.005655

Mason, C., Carter, S. \& Tagg, S. (2008). Invisible businesses: the characteristics of home-based businesses in the United Kingdom. Glasgow: Working paper 08-01, University of Strathclyde Business School.

Minniti, M., Bygrave, W. \& Autio, E. (2006). Global Entrepreneurship Monitor: 2005 Executive Report. London: London Business School. 
Nelson, E. \& Bruijn, E. (2005). The voluntary formation of enterprises in a developing economy: the case of Tanzania. Journal of International Development, 17, 575-93. http://dx.doi.org/10.1002/jid.1176

Otero, M. (1994). The role of governments and private institutions in addressing the informal sector in Latin America. In C. A. Rakowski (Ed.), Contrapunto: the informal sector debate in Latin America (pp. 177-198). New York: State University of New York Press.

Perry, G. E., Maloney, W. F., Arias, O. S., Fajnzylber, P., Mason, A. D., Saavedra-Chanduvi, J. (Eds.). Informality: exit and exclusion. Washington DC: World Bank.

Perry, G. E. \& Maloney, W. F. (2007). Overview: Informality - exit and exclusion. In G. E. Perry, W. F. Maloney, O. S. Arias, P. Fajnzylber, A. D. Mason and J. Saavedra-Chanduvi. (Eds.), Informality: exit and exclusion (pp. 1-20). Washington DC: World Bank. http://dx.doi.org/10.1596/978-0-8213-7092-6

Perunović, Z. (2005). Introducing Opportunity-Based Entrepreneurship in a Transition Economy. Michigan: Policy Brief 39, William Davidson Institute, University of Michigan.

Portes, A. (1994). The informal economy and its paradoxes. In N. J. Smelser and R. Swedberg (Eds.), The Handbook of Economic Sociology (pp. 141-169). Princeton: Princeton University Press.

Portes, A. \& Haller, W. (2004). La economía informal. Santiago: Seria Políticas Sociales 100. División de Desarrollo Social - CEPAL, United Nations.

Portes, A. \& Roberts, B. (2005). The free-market city: Latin American urbanization in the years of the neoliberal experiment. Studies in Comparative International Development, 40, 43-82. http://dx.doi.org/10.1007/BF02686288

Rakowski, C. (1994). The informal sector debate, part II: 1984-1993. In C. A. Rakowski (ed.), Contrapunto: the informal sector debate in Latin America (pp. 79-101). New York: State University of New York Press.

Reynolds, P., Camp, S. M., Bygrave, W. D., Autio, E. \& Hay, M. (2001). Global Entrepreneurship Monitor: 2001 Executive Monitor. London: London Business School.

Reynolds, P., Bygrave, W. D., Autio, E. \& Hay, M. (2002). Global Entrepreneurship Monitor: 2002 Executive Monitor. London: London Business School.

Round, J. \& Williams, C. C. (2008). Everyday tactics and spaces of power: the role of informal economies in post-Soviet Ukraine. Social and Cultural Geography, 9, 171-185. http://dx.doi.org/10.1080/14649360701856110

Round, J., Williams, C. C. \& Rodgers, P. (2008). Corruption in the post-Soviet workplace: the experiences of recent graduates in contemporary Ukraine. Work, Employment and Society 22, 149-166. http://dx.doi.org/10.1177/0950017007087421

Rouse, M. \& Dallenbach, U. (1999). Rethinking research methods for the resource-based perspective: isolating sources of sustainable competitive advantage. Strategic Management Journal 20, 487-494. http://dx.doi.org/10.1002/(SICI)1097-0266(199905)20:5<487::AID-SMJ26>3.0.CO;2-K

Sassen, S. (1997). Informalisation in Advanced Market Economies. Geneva: Issues in Development Discussion Paper 20, International Labour Organisation.

Schneider, F. \& Williams, C. C. (2013). The Shadow Economy. London: Institute of Economic Affairs. http://dx.doi.org/10.1017/CBO9781139542289

Small Business Council (2004). Small Business in the Informal Economy: making the transition to the formal economy. London: Small Business Council.

Smallbone, D. \& Welter, F. (2004). Entrepreneurship in transition economies: necessity or opportunity driven?, www.babson.edu/entrep/fer/BABSON2003/XXV/XXV-S8/xxv-s8.htm (last accessed 9 April 2013)

Snyder, K. A. (2004). Routes to the Informal economy in New York's East village: crisis, economics and identity. Sociological Perspectives, 47, 215-240. http://dx.doi.org/10.1525/sop.2004.47.2.215

Staudt, K. (1998). Free Trade? informal economies at the US-Mexico Border. Philadelphia: Temple, University Press.

Tokman, V. (2001). Integrating the informal sector in the modernization process. SAIS Review, 2, 45-60. http://dx.doi.org/10.1353/sais.2001.0027

Travers, A. (2002). Prospects for Enterprise: an investigation into the motivations of workers in the informal economy. London: Evidence paper No.2, Community Links. 
Unni, J. \& Rani, U. (2003). Employment and income in the informal economy: a micro-perspective. In R. Jhabvala, R. M. Sudarshan and J. Unni (Eds.), Informal Economy Centrestage: new structures of employment (pp. 39-61). London: Sage.

Venkatesh, S. A. (2006). Off the books: the underground economy of the urban poor. Cambridge, MA: Harvard University Press.

Webb, J. W., Tihanyi, L., Ireland, R. D. \& Sirmon, D. G. (2009). You say illegal, I say legitimate: entrepreneurship in the informal economy. Academy of Management Review, 34, 492-510. http://dx.doi.org/10.5465/AMR.2009.40632826

Williams, C. C. (2004) Cash-in-Hand Work: the underground sector and hidden economy of favours. Basingstoke: Palgrave Macmillan. http://dx.doi.org/10.1057/9780230506190

Williams, C. C. (2005). The undeclared sector, self-employment and public policy. International Journal of Entrepreneurial Behaviour and Research, 11, 244-257. http://dx.doi.org/10.1108/13552550510603289

Williams, C. C. (2006). The Hidden Enterprise Culture: entrepreneurship in the underground economy. Cheltenham: Edward Elgar. http://dx.doi.org/10.4337/9781847201881

Williams, C. C. (2007). Entrepreneurs operating in the informal economy: necessity or opportunity driven? Journal of Small Business and Entrepreneurship, 20, 309-320. http://dx.doi.org/10.1080/08276331.2007.10593402

Williams, C. C. (2008). Beyond necessity-driven versus opportunity-driven entrepreneurship: a study of informal entrepreneurs in England, Russia and Ukraine. International Journal of Entrepreneurship and Innovation, 9, 157-166. http://dx.doi.org/10.5367/000000008785096647

Williams, C. C. (2009a). Entrepreneurship and the off-the-books economy: some lessons from England. International Journal of Management and Enterprise Development, 7, 429-444. http://dx.doi.org/10.1504/IJMED.2009.026308

Williams, C. C. (2009b). The motives of off-the-books entrepreneurs: necessity- or opportunity-driven?. International Entrepreneurship and Management Journal, 5, 203-217. http://dx.doi.org/10.1007/s11365-008-0098-8

Williams, C. C. (2009c). The hidden enterprise culture: entrepreneurs in the underground economy in England, Ukraine and Russia. Journal of Applied Management and Entrepreneurship, 14, 44-60.

Williams, C. C. (2010). Spatial variations in the hidden enterprise culture: some lessons from England. Entrepreneurship and Regional Development, 22, 403-423. http://dx.doi.org/10.1080/08985620903168281

Williams, C. C. \& Gurtoo, A. (2013). Beyond entrepreneurs as heroic icons of capitalism: a case study of street entrepreneurs in India. International Journal of Entrepreneurship and Small Business, 19, 421-437. http://dx.doi.org/10.1504/IJESB.2013.055485

Williams, C. C. \& Lansky, M. (2013). Informal employment in developed and emerging economies: perspectives and policy responses. International Labour Review, 152, 355-380. http://dx.doi.org/10.1111/j.1564-913X.2013.00196.x

Williams, C. C. \& Nadin, S. (2011). Entrepreneurs in the shadow economy: economic or social entrepreneurs?. International Journal of Management and Enterprise Development, 11, 20-33. http://dx.doi.org/10.1504/IJMED.2011.042970

Williams, C. C. \& Nadin, S. (2012a). Tackling entrepreneurship in the informal economy: evaluating the policy options. Journal of Entrepreneurship and Public Policy, 1, 111-124. http://dx.doi.org/10.1108/20452101211261408

Williams, C. C. \& Nadin, S. (2012b). Tackling the hidden enterprise culture: government policies to support the formalization of informal entrepreneurship. Entrepreneurship and Regional Development, 24, 895-915. http://dx.doi.org/10.1080/08985626.2012.742325

Williams, C. C. \& Nadin, S. (2013a). Beyond the entrepreneur as a heroic figurehead of capitalism: re-representing the lived practices of entrepreneurs. Entrepreneurship and Regional Development, 25, 552-568. http://dx.doi.org/10.1080/08985626.2013.814715

Williams, C. C. \& Nadin, S. (2013b). Harnessing the hidden enterprise culture: supporting the formalization of off-the-books business start-ups. Journal of Small Business and Enterprise Development, 20, 434- 447. http://dx.doi.org/10.1108/14626001311326815

Williams, C. C., Nadin, S. \& Rodgers, P. (2011). Evaluating competing theories of informal entrepreneurship: some 
lessons from Ukraine. International Journal of Entrepreneurial Behaviour and Research, 18, 528-543.

Williams, C. C., Nadin, S., Newton, S., Rodgers, P. \& Windebank, J. (2013a). Explaining off-the-books entrepreneurship: a critical evaluation of competing perspectives. International Entrepreneurship and Management Journal, 9, 447-463. http://dx.doi.org/10.1007/s11365-011-0185-0

Williams. C. C. \& Round, J. (2009). Evaluating informal entrepreneurs' motives: some lessons from Moscow. International Journal of Entrepreneurial Behaviour and Research, 15, 94-107. http://dx.doi.org/10.1108/13552550910934477

Williams, C. C., Round, J. \& Rodgers, P. (2006). Beyond necessity- and opportunity-driven entrepreneurship: some case study evidence from Ukraine. Journal of Business and Entrepreneurship, 18, 22-34.

Williams, C. C., Round, J. \& Rodgers, P. (2009). Evaluating the motives of informal entrepreneurs: some lessons from Ukraine. Journal of Developmental Entrepreneurship, 14, 59-71. http://dx.doi.org/10.1142/S1084946709001144

Williams, C. C., Round, J. \& Rodgers, P. (2010). Explaining the off-the-books enterprise culture of Ukraine: reluctant or willing entrepreneurship?. International Journal of Entrepreneurship and Small Business, 10, 65-80. http://dx.doi.org/10.1504/IJESB.2010.033107

Williams, C. C., Round, J. \& Rodgers, P. (2013b). The Role of Informal Economies in the Post-Soviet World: the end of transition?. London: Routledge.

Williams, C. C. \& Windebank, J. (1998). Informal Employment in the Advanced Economies: implications for work and welfare. London: Routledge. 